\title{
Erratum to: Single- and repeated-dose oral toxicity tests of deep sea water mineral extracts in ICR mice
}

\author{
Min Hee Hwang ${ }^{1} \cdot$ Miju Cho ${ }^{1} \cdot$ Dong Gun Lee ${ }^{1} \cdot$ Eun Byeol Go $^{1} \cdot$ \\ Young Sig Park ${ }^{2} \cdot$ Namhyun Chung ${ }^{1}$
}

\section{Erratum to: J Appl Biol Chem (2016) 59, 227-231 DOI 10.3839/jabc.2016.039}

p. 231

We will modify the Acknowledgments.

The online version of the original article can be found under doi: 10.3839/jabc.2016.039
Acknowledgments This research was a part of the project titled 'Evaluation of Food Safety on Deep Sea Water Mineral Extract', funded by the Ministry of Oceans and Fisheries, Korea.

Min Hee Hwang and Miju Cho contributed equally.

Namhyun Chung $(\bowtie)$

E-mail: nchung@korea.ac.kr

Young Sig Park $(\bowtie)$

E-mail:pysku@korea.ac.kr

${ }^{1}$ Department of Biosystems Engineering, College of Life Sciences and Biotechnology, Korea University, Seoul 02841, Republic of Korea

${ }^{2}$ Functional Food Research Center, College of Life Sciences and Biotechnology, Korea University, Seoul 02841, Republic of Korea

This is an Open Access article distributed under the terms of the Creative Commons Attribution Non-Commercial License (http://creativecommons. org/licenses/by-nc/3.0/) which permits unrestricted non-commercial use, distribution, and reproduction in any medium, provided the original work is properly cited. 